\title{
AUSTRALASIAN HISPIDAE OF THE GENERA BRONTHISPA AND PROMECOTHECA WHICH DESTROY COCONUT PALM FRONDS.
}

\author{
By Walter W. Froggatt, F.L.S., \\ Government Entomologist, New South Wales.
}

With the increasing demand for copra all over the world for the production of coconut oil, the cultivation of coconut palms has increased enormously during the last ten years in the Solomon Islands, New Britain, Papua, Samoa, and the New Hebrides, and large areas of virgin forest have been cleared and planted on regulär scientific principles. In olden times most of the nuts were collected from the native plantations, where the palms were grown under almost wild forest conditions, and were then more hardy and did not suffer to the same extent from insect pests as do the palms planted under modern conditions. It is probable that the inereased food supply, represented in the fronds of the thousands of young coconut palms planted out, has been responsible for the enormous increase of a number of indigenous leafeating beetles, which, under the conditions previously prevailing, lived upon the wild coconut and other species of palms growing in the jungle. In addition to many insect pests allied to or identical with those known in Ceylon, India, and the Malay States, we have in these Eastern islands a number of leaf-destroyers in the small flattened beetles belonging to the family HISPIDAE. The larvae of these beetles feed either on the upper surface, or in the tissue of the leaf under the protection of which they finally. pupate, so that one can sometimes obtain the whole life-history from the egg to the perfect insect in a single palm frond. The majority of these leaf beetles, which are causing so much damage in the coconut plantations, belong to the genus Promecotheca, Blanchard, and from what we know of the life-history of several species that have become serious pests, it is fairly safe to assume that the habits of all the species are similar.

The described species given by Weise in the "Genera Insectorum" (1911) number 15, and range from China to the New Hebrides. The following ones occur in the area under survey, and notes are given upon those that have been recorded as pests of coconut palms. The life-histories of the different species of this genus are so similar that it is here only necessary to give that of a typical one, and $I$ have selected for this purpose the species in the New Hebrides, which has done such an enormous amount of harm during the last few years to the coconut plantations.

\section{The New Hebrides Coconut Hispid (Promecotheca opacicollis).}

This insect is known among the planters as " the Blight," "the Fly," or " the Beetle Pest" of the coconut palm, and is said to have been noticed by some of the settlers in the islands over 50 years ago. About 1905 they were first recorded in the Northern Islands of the group, damaging palms in the cultivated plantations, and three years ago there was a regular plague of them all over the islands, from Sandwich to Santo. At the request of a number of planters interested, I paid a visit to the New Hebrides in June 1913, and spent over a month among the coconut plantations studying the insect pests, and this beetle in particular.

The damage done is twofold; first, that caused by the larvae; and secondly, that caused by the adult beetles. The beetles lay their eggs in little clusters of five 
upon the under surface of the palm frond, covering them with a little mound of chewedup fibre. Under this protection the larvae hatch out and gnaw their way between the two layers of the leaf, feeding as they go, until they have excavated a regular gallery, forming a brown blister up to six inches in length and half an inch in width. When fully fed the larvae pupate at the end of excavation. The elongated blisters in the fronds shrivel up and, when numerous, the whole frond is destroyed. The beetles, however, do more damage than the larvae, because while swarming over the under surface of the leaves, and also while laying their eggs, they feed upon the fronds, gnawing long parallel furrows down the centre. Besides the damage caused by the beetles and their larvae, each of these damaged fronds becomes a centre of infection for the fungus diseases which are so prevalent in the tropics. Each frond dies back to the mid-rib or main stalk, which turns brown and decays down to its junction with the trunk of the palm. Behind the basal fronds are produced the flower spathes, afterwards replaced by the bunches of coconuts, and when these fronds fall from the trunk, the coconuts as they increase in size are unable to sustain their own weight, and are, therefore, torn off from the attachment to the stem of the palm, and fall to the ground while still immature and of no commercial value.

Therefore, after the beetle infestation, the crop is very poor, unless the coconuts happen to have been well matured before the beetles attacked the foliage. In the season following an attack by Hispids the coconut palms, denuded of all these lower leaves, have to grow a fresh crop of foliage before they can put forth fresh flower spathes; the annual output is thus less than that of the previous year, and often it is not until the following season that the coconut palms have absolutely regained their former vigour. It is frequently stated by the planters that the palms are killed outright by these beetles. But the coconut is a very hardy tree, and as long as the terminal leaf-buds are uninjured they will put forth fresh leaves and recover sooner or later from the attacks of the beetles, unless these are followed by a continuous drought or other abnormal conditions, when the enfeebled palms cannot withstand the additional strain.

\section{The Fiji Coconut Hispid (Promecotheca coeruleipennis, Blanchard).}

This is the type of this genus of destructive beetles, and was described from Fiji by Blanchard from specimens obtained during the voyage of the "Astrolabe," which was sent out by order of the King of France on a scientific expedition in 1837-40. The insect is described and figured in the Zoology of the expedition published in Paris in 1853. From Blanchard's figure and description this appears to be the common leaf Hispid of the coconut in Fiji, although in Jepson's report it is identified as Promecotheca reichii, a species which, according to Gestro, may be a variety of $\boldsymbol{P}$. coeruleipennis.

Jepson has described and figured the life-history of this insect, and states that it has only been found upon a few of the islands. It is therefore a local pest, and is not, like the New Hebrides species, spread all over the group, though its life-history and habits are identical. It is abundant in March and April, but is heavily parasitised in the egg, larval and pupal stages. The parasite, which is a different hymenopteron from that which is found attacking the eggs of the Leaf Hispa of the New Hebrides, seems to be a useful check upon its increase in Fiji. 
The beetle is smaller than $P$. opacicollis and differs in having the antennae lightcoloured on the basal joints, with the head (except the eyes), thorax, legs and basal third of the wing-covers yellow and the hind two-thirds of the wing-covers deep metallic purple to blue.

The solomon Is. Coconut Hispid (Promecotheca antiqua, Weise).

The writer did not notice this beetle during his visit to the Solomon Islands, but subsequently received a number of specimens from Bougainville. It had been previously recorded from New Britain and German New Guinea, where it is known as a leaf pest of the coconut palm. Closely allied to $P$. opacicollis in size and general form, it differs in having the basal joints of the antennae more ferruginous, the head and thorax black, the wing-covers more rugose, not so deeply striated, of a uniform light colour for the first three-quarters and the apical quarter black.

The Qucensland Coconut Hispid (Promecotheca callosa, Baly).

This species is found in Northern Australia upon native palms. There are several specmens in the Macleay Museum collections from Cape York, Queensland. It measures slightly over one-third of an inch in length and is somewhat broader across the shoulders than most of the species previously noticed. The head, thorax, antennae, and under surface are black, with only the tips of the tarsi golden yellow. The elytra are yellow, swelling out on the front margin, but of a uniform width, broadly rounded to the tips, and ornamented with eight parallel striae on either side, impressed with small deep contiguous punctures. Nothing has been recorded of the habits or exact food-plant of this beetle.

\section{The Port Darwin Coconut Hispid. (Promecotheca varipes, Baly).}

This species is represented by several specimens in the Macleay Museum. Mr. Lea informs me that there is a specimen in the Adelaide Museum from the same locality (Port Darwin, N. Australia) obtained upon the foliage of Pandanus.

About the same size as the previous species, it has the head, thorax, fore legs and elytra yellow; the tarsi, the junction of the femur and tibia of the fore legs, the antennae, the middle and hind legs, and the under surface black. The thorax is deeply constricted by three transverse rounded ridges, the central one the broadest. The elytra swelling out in front, broadly rounded to the apex, with similar parallel striae, but the punctures deeper than in $P$. callosa.

Two species have been described from German New Guinea by the Hungarian Entomologist, Csiki, Promecotheca biroi and P. papuana, but neither has as yet been recorded, so far as I know, as a pest of coconuts.

The Leal-bud Hispa (Bronthispa froggatti, Sharp).

The larvae of the beetles of this genus are not leaf-miners, but feed with the adult beetles upon the epidermis of the opening leaf-buds, protected in the half-folded fronds. This species is included here as it has done a great deal of damage and caused much extra expense in the work of looking after the young coconut palms in the plantations in many parts of the Solomons.

The beetle, larvae and pupae may be all found together in the same palm frond, so that their life-history can be easily studied. Both the beetles and larvae gnaw 
the surface of the leaf, which, as it expands, shows large blackened areas through the damage thus caused; and where the leaves are badly infested they keep dying back one after another, so that the growth of the palm is seriously retarded.

Originally described from specimens sent to Dr. Sharp by me and obtained in plantations in New Britain, this beetle was found a few years later swarming in the coconut plantations in the Solomon Islands It has, however, a still wider range, for last year (1913) I discovered it in many parts of the New Hebrides, where it was usually to be found in the fronds of any small, sickly or damaged tree, but was not a pest on healthy cultivated palms, as it was in New Britain and the Solomon Islands.

The beetle is slender, almost cylindrical in the body, and tapering at the tip of the abdomen; from the tip of the antennae it measures up to half an inch in length. General colour shining black, with the thorax and fore pair of legs dull yellow, the second pair marked with yellow. The small head is produced in front into a lanceshaped projection between the antennae ; the thorax almost square, slightly hollowed out on the sides, and curved round in front behind the eyes. The slender body is covered with stout black wing-covers, deeply ribbed with finely punctured striae, depressed and rounded at the extremities.

At first the chief method adopted in dealing with these beetles and their larvae was to apply a tobacco and soap wash. This was effective when shaken or sprayed into the infested fronds, but the difficulty was to see that the native boys did the work properly. Afterwards and at the present time, when "beetling" is carried out, the tips of the infested fronds are cut off as soon as noticed and burnt with the eggs and larvae before they have spread downwards to damage the whole of the young leaf. 